husband, a tool-setter, died from cancer of the scrotum attributed to exposure to mineral oil. The case arose in one of the bigger and cleaner factories and might never have been recognized as a case of industrial cancer or come to court if it had arisen in a smaller concern. As a result, notices warning of the dangers of exposure to mineral oil have been renewed or displayed more prominently in engineering shops, and by the distribution of pamphlets the attention of workers has been drawn to the hazards-particularly the danger of delay in seeking medical advice. Recently, too, the Department of Employment and Productivity and the Factory Inspectorate have jointly produced a new and more informative warning pamphlet."

Despite these efforts a visit to some engineering factories would probably still show men not wearing aprons, men wearing oil-soaked overalls and putting oily rags in their trouser pockets, and men with oil on their faces and hands who make little use of the washing facilities provided. It is an unwritten basic human right that a man cannot be forced to keep himself clean, and some men in this country seem to regard cleanliness as an infringement of manhood, though the position has perhaps improved since Henry Butlin, in these columns in $1892,{ }^{8}$ contrasted English chimney sweepers with some of their Continental counterparts, particularly in Switzerland and Germany.

Is the answer to make the oil safe to use ? Mineral oils consist of three types of compound-paraffins, naphthenic compounds, and aromatic compounds. It is thought that most of the carcinogenicity of cutting oils is attributable to compounds in the aromatic fraction, particularly the polycyclic aromatics containing 4 to 6 condensed benzene rings. ${ }^{910}$ But some straight chain aliphatic compounds such as dodecane $^{11}$ have been shown to enhance the carcinogenic activity of polycyclic aromatic compounds for mouse skin. Some commonly used additives such as sulphur itself and certain other sulphur-containing compounds may also do so, ${ }^{12}$ and so may certain phenols. ${ }^{13}$

For some engineering purposes it might be possible to use the highly refined "white oils" recommended for use in the textile industry, but they are relatively expensive, would be scarce if the demand increased, and suffer from the disadvantage that they do not have quite the same physical properties as oils used at present. They also have poor solvency for some of the additives used in special metal-working oils.

1 Henry, S. A., Cancer of the Scrotum in Relation to Occupation. London, Oxford University Press, 1946

2 Ministry of Labour and National Service, The Mule Spinning (Health) Special Regulations 1953 (S.I. 1545). London, H.M.S.O. 1953.

3 Cruickshank, C. N. D., and Squire, J. R., British fournal of Industrial Medicine, 1950, 7, 1.

4. Cruickshank, C. N. D., and Gourevitch, A., British fournal of Industrial Medicine, 1952, 9, 74.

5 Fife, J. G., British fourmal of Industrial Medicine, 1962, 19, 123.

6 Stokes $v$. Guest Keen and Nettlefold (Bolts and Nuts) Ltd., Solicitors

7 Department of Employment and Productivity, Cancer of the Skin Caused by Oil, pamphlet No. SHW 295A. London, H.M.S.O. 1969.

8 Butlin, H. T., British Medical fournal, 1892, 1, 1341; 2, 1 ; and

9 Bingham, E., Horton, A. W., and Tye, R., Archives of Environmental Health, 1965, 10, 449.

10 Dietz, W. A., King, W. H., Priestley, W., and Rehner, J., Industrial and Engineering Chemistry, 1952, 44, 1818.

11 Horton, A. W., Denman, D. T., and Trosset, R. P., Cancer Research, 1957, 17, 758 .

12 Horton, A. W., Bingham, E. L., Burton, M. J. G., and Tye, R., Cancer Research, 1965, 25, 1759.

13 Boutwell, R. K., and Bosch, D. K., Cancer Research, 1959, 19, 413.

16 Sutton, M., British Medical fournal, 1969, 1, 116.

1s Lloyd, W. J., British Medical fournal, 1968, 4, 830.

16 Kinnear, J., Rogers, J., Finn, O. A., and Mair, A., British fournal of Industrial Medicine, 1955, 12, 36.

17 Roe, F. J. C., Carter, R. L., and Taylor, W., British fournal of Cancer, 1967, 21, 694.
Doubtless now that attention has been drawn to the need for less hazardous oils they will be developed, though they will be more expensive. But it would be a mistake at present to rely on them as the immediate or only solution to the problem.

General practitioners have an important role in the diagnosis of the condition. Clearly the significance of a wart or ulcer on the scrotum or vulva needs careful assessment. Another aspect of the problem is that not all skin cancers of industrial origin are being notified, ${ }^{14}$ and there is no means of finding out what the short-fall is. An important reason for failure to notify is lack of awareness that skin cancer of industrial origin often arises long after exposure to the causative agent has ceased, and frequently after a person has retired from work altogether. These problems would be partly solved if employers were required by law to introduce six-monthly medical examinations by experienced factory doctors of workers heavily exposed to mineral oils. How many workers should be covered by such a recommendation is difficult to say, but medical resources are too few for all workers exposed to mineral oils to be included..$^{15}$ At least a beginning could be made with those occupations in which there is an established risk, such as tool-setting and jute manufacture. ${ }^{16} 17$

\section{A New Synthetic Antimycotic}

Since the discovery of nystatin nearly twenty years ago the treatment of fungus infections has been mainly with antibiotics. Nystatin can cope with most forms of candidiasis, while griseofulvin, rediscovered as an antimycotic some years later, can deal with the dermatophytoses and amphotericin B with systemic mycoses, histoplasmosis, coccidioidomycosis, and deep-seated forms of candidiasis. Some of these treatments, particularly the last-named owing to its toxic effects, leave something to be desired, and the advent of a totally new drug with some promise in this direction is consequently welcome.

Such a drug is described by $M$. Plempel and his colleagues, ${ }^{1}$ of the Bayer laboratories in Elberfeld. Known at present only as BAYb 5097, it is bis-phenyl(2-chlorphenyl)-1-imidazolylmethane, and is one of 600 similar derivatives recently synthesized and presumably examined for any useful form of activity. It has no action on bacteria, but inhibits the growth of a large variety of fungi, including plant as well as human pathogens, in concentrations usually about $1 \mu \mathrm{g} . /$ $\mathrm{ml}$. The species of which multiple strains have been tested with consistent results include the principal dermatophytes, Candida, Aspergillus, and Penicillium species, Histoplasma capsulatum, Coccidioides immitis, Cryptococcus neoformans, and Sporotrichum schenckii.

The L.D. ${ }_{50}$ for animals is about $1,000 \mathrm{mg} . / \mathrm{kg}$. body weight, and doses of 150 and $60 \mathrm{mg} . / \mathrm{kg}$. daily have been given to animal and man respectively with no evident ill effects. Presumably because of its low solubility in water very little is absorbed after parenteral injection, but by a mechanism which is not altogether clear its absorption from the alimentary tract is good, a single dose of $40 \mathrm{mg} . / \mathrm{kg}$. in man pro-

\footnotetext{
2 Plempel, M., Bartmann, K., Buchel, K. H., Regel, E., Deutsche Medizinische Wochenschrift, 1969, 94, 1356.

2 Oberste-Lehn, H., Baggesen, I., and Plempel, M., Deutsche Medizinische Wochenschrift, 1969, 94, 1365. 
ducing a blood level of $2-4 \mu \mathrm{g} . / \mathrm{ml}$. at four hours, falling slowly thereafter. About half of the drug in man (though only $10 \%$ in mice and rats) is in the form of an inactive metabolite; this metabolite alone is found in the urine of all species. Animal experiments have given evidence of therapeutic efficacy. A single dose protected $95-100 \%$ of mice inoculated one hour later with Histoplasma capsulatum. In mice inoculated intravenously with Candida albicans survival rates of $40,80,90$, and $100 \%$ were achieved with increasing doses given for five days, and the count of organisms in the kidney was shown to fall almost to nil. Similar results were obtained in infection with Aspergillus fumigatus and $A$. nidulans, and local treatment was effective in $T$. mentagrophytes infection in guinea-pigs.

The succeeding paper by $\mathrm{H}$. Oberste-Lehn and his colleagues $^{2}$ describes the treatment of three patients with this drug. All received a total daily dose of $60 \mathrm{mg} . / \mathrm{kg}$. body weight for varying periods, and apart from some apparent gastric intolerance in two of them, which could be overcome, there were no side-effects. One patient was a young man with sycosis barbae from which Candida albicans was cultivated. Only 15 days' treatment led to resolution, and the organism also disappeared from the faeces, in which it had been found before. A 59-year-old woman developed a typical aspergilloma at the site of a lung abscess after a postoperative infarct. After two months' treatment $A$. fumigatus disappeared from the sputum, and later the lesion underwent progressive shrinkage ; treatment was being continued after nine months at the time of writing. Thirdly, an asthmatic woman aged 62 developed a Candida krusei infection, with copious mucopurulent sputum and deterioration in both pulmonary and cardiac function. Treatment for an unstated period relieved these conditions and reduced the frequency of asthmatic attacks and the Candida content of the sputum.

This drug appears to have two outstanding advantages: it is easily administered and well tolerated, and almost all fungi pathogenic to man are susceptible to it. Moreover, this susceptibility has been verified in vivo for representatives of some of the principal genera by therapeutic tests in animals. The clinical observations are of a wholly preliminary nature, but encouraging enough to demand that they be extended both in numbers and to other forms of mycosis.

\section{Lymphoma and Glandular Fever}

Infectious mononucleosis or glandular fever has long been known to be infectious, but its cause has been elusive. At various times it has been ascribed to toxoplasma, bacteria, or viruses, but recent evidence shows that most cases with a heterophile antibody (Paul-Bunnell) response are associated with infection by a virus similar or identical to the EpsteinBarr virus ${ }^{1-3}$ found in cell lines from Burkitt lymphomas.

A syndrome similar to infectious mononucleosis but without a heterophile response can be caused by cytomegalovirus. ${ }^{4-6}$ Workers in America ${ }^{7-10}$ and now in Britain ${ }^{11}$ have shown that cases with a heterophile response show increases in or already have high antibody titres against the Epstein-Barr virus. A small proportion have virus antibody but not heterophile responses. Two methods of measuring antibody have been used: either a complement fixation test using an EpsteinBarr virus antigen, or more commonly an indirect fluorescent antibody technique using Burkitt tumour cells infected with the virus, the membrane of the cells being specifically antigenic. ${ }^{7-12}$ The antibodies detected by these methods can apparently be distinguished. ${ }^{13}$ The nature of heterophile antibody remains obscure but can be distinguished from these virus antibodies. ${ }^{10}$

Infections with a virus or viruses like the Epstein-Barr organism are probably much commoner than recognized infectious mononucleosis. In America antibody was found in $35-57 \%$ of children, $24 \%$ of healthy Yale students, and $90 \%$ of healthy adults or cancer patients. ${ }^{72}{ }^{14}$ In Sweden $90 \%$ of babies had antibody at birth (presumably maternai in origin), $12 \%$ at age 2 , and $90 \%$ at 20 years of age. ${ }^{15}$ In Africa antibody is at least as common, ${ }^{74}$ and the lack of evidence of much infectious mononucleosis is probably attributable to lack of diagnostic facilities. It seems likely, moreover, that in underdeveloped countries infection occurs earlier in life. Antibody appears to persist without loss of titre for long periods. ${ }^{12}$ Every patient with Burkitt's lymphoma and a high proportion of those with carcinoma in the post-nasal space have antibody, usually at higher titres than in infectious mononucleosis. ${ }^{76}$

The Epstein-Barr virus is a distinct member of the herpes virus group but does not grow in cell systems normally susceptible to the group. ${ }^{15} \quad$ Apart from one report of transmission to thymectomized mice, ${ }^{18}$ this virus (or viruses) appears to grow only in cultured human cells ${ }^{19}$ of the haemopoietic system. V. Diehl and colleagues ${ }^{20}$ found that all cultures of peripheral leucocytes from cases of infectious mononucleosis grew readily, and Epstein-Barr virus was found in all. Cultures grew from only five out of seven patients with a history of the disease and only in the presence of human diploid cells, whereas no cultures could be established from patients without a history and without antibody

2 Epstein, M. A., Achong, B. G., and Barr, Y. M., Lancet, 1964, 1, 702.

- Epstein, M. A., Barr, Y. M., and Achong, B. G., in Methodological Approaches to the Study of Leukemias, ed. V. Defendi, p. 69. Philadelphia, Wistar Institute. 1965.

stewart, S. E., Lovelace, E., Whang, J. J., and Ngu, V. A., fournal of the National Cancer Institute, 1965, 34, 319.

- Klemola, E., and Kääriäinen, L., British Medical fournal, 1965, 2, 1099.

s Klemola, E., Käriäinen, L., Von Essen, R., Haltia, K., Koivunieml, A., and Von Bonsdorff, C.'H., Acta Medica Scandinavica, 1967, 182, A., an.

- Stern, H., British Medical fournal, 1968, 1, 665.

Henle, G., Henle, W., and Diehl, V., Proceedings of the National Academy of Sciences, 1968, 59, 94 .

- Niedermann, J. C., McCollum, R. W., Henle, G., and Henle, W., fournal of the American Medical Association, 1968, 208, 205.

- Evans, A. S., Niedermann, J. C., and McCollum, R. W., New England fournal of Medicine, 1968, 279, 1121

${ }^{10}$ Gerber, P., Hamre, D., Moy, R. A., and Rosenblum, E. N., Science,

1968, 161, 173.

12 Gerber, P., and Birch, S. M., Proceedings of the National Academy

is Pearson, G., Klein, G., Henle, G., Henle, W., and Clifford, P., fournal of Experimental Medicine, 1969, 129, 707.

14 Levy, J. A., and Henle, G., fournal of Bacteriology, 1966, 92, 275.

15 Demissie, A., and Svedmyr, A., Acta Pathologica Microbiologica Scandinavica, 1969, 75, 457.

16 Klein, G., et al., fournal of Experimental Medicine, 1969, 129, 697.

${ }_{17}$ Moses, H. L., et al., Proceedings of the National Academy of Sciences, $1968,60,489$.

18 Stewart, S. E., Glazer, D., Ben, T., and Lloyd, B. J., jun., fournal of the National Cancer Institute, 1968, 40,423.

19 Henle, W., Diehl, V., Kohn, G., Hausen, H., and Henle, G., Science, $1967,157,1064$.

so Diehl, V., Henle, G., Henle, W., and Kohn, G., fournal of Virology, 1968, 2, 663.

21 Jensen, E. M., Korol, W., Dittmar, S. L., and Medrek, T. J., fournal of the National Cancer Institute, 1967,39, 745 .

32 Zeve, V. H., Lucas, L. S., and Manaker, R. A., Fournal of the National Cancer Institute, 1966, 37, 761 .

2s Pope, J. H., Australian fournal of Experimental Biology and Medical Science, 1968, 46, 643.

24 Moore, G. E., Gerner, R. E., and Franklin, H. A., fournal of the American Medical Associdtion, 1967, 199, 519. 